DOI https://doi.org/10.18551/rjoas.2017-11.34

\title{
THE IMPLEMENTATION OF ENVIRONMENTAL COSTS IN COMPANY TO REDUCE ENVIRONMENTAL IMPACT
}

\author{
Dyani* ${ }^{*}$ Mitra Dindha Ayu \\ Faculty of Administrative Science, University of Brawijaya, Indonesia \\ *E-mail: dindhaayu@ub.ac.id
}

\begin{abstract}
The implementation of environmental costs in the company becomes mandatory nowadays to fulfill the concept of sustainable development. Emdeki Utama, Ltd., a carbore-producing company, has implemented environmental costs and shown that the allocation of funds is not only able to effectively reduce the environmental impact (waste content) resulted from the production process, but also to improve the quality of life of the community around the company.
\end{abstract}

\section{KEY WORDS}

Environmental costs, waste content, living quality, community.

Indonesia has ratified the international agreement on sustainable development and become as part of countries that are committed to run programs to reduce the rate of greenhouse gas emissions and environmental damages. The concept of sustainable development has been encouraged, as the concept that aims to create a balance between development dimensions, such as economic, social and environmental developments. This concept is a principled development process meeting current needs without compromising the fulfillment of future generations (Pearce, David 1997). This commitment shall be demonstrated through policies of the countries in development activities.

One of the policies in relation to promote sustainable development is to regulate the activities of companies utilizing natural resources, namely Articles 2 and 3 of Government Regulation Number 47 of 2012 on Social and Environmental Responsibility, explaining that any companies that run on business in the field of natural resources shall be obligated to carry out social and environmental responsibility that should be implemented in the form of environmental costs.

This environmental cost should be allocated to prevent the decline in the quality as well as the quantity of human life and natural resources. This situation encourages the company to run the process of transforming the environment-based business to address the issues related to sustainability of the natural resources.

\section{LITERATURE REVIEW}

Environmental costs are the costs specially allocated by the company related to the environmental damage due to business operation and the protection to the environment should be conducted (Susenohaji, 2003). Environmental costs can be categorized into four aspects: prevention costs, detection costs, internal failure costs, and external failure costs.

Environmental prevention costs are costs allocated for any activities undertaken to prevent the waste as the result of production process that may cause environmental pollution, such as supplier evaluation and selection, including studies on environmental impact. Environmental detection costs are incurred to determine whether the products, processes, and other activities at the company have met the applicable standards based on the concept of sustainability, such as audits on environmental activities, pollution testing, and pollution levels,

The cost on internal environmental failure is utilized for activities carried out due to the production of waste, but not disposed of into the external environment. Such activities are processing and disposal of toxic wastes, licensing facilities for producing waste, and 
recycling waste materials. The cost on external environmental failure is the costs incurred after releasing company's waste into the environment.

Burnett and Hansen (2008) argue that if a company wants to improve its environmental performance, the environmental costs must be carried out to perform the collection, calculation, analysis and reporting of transactions related to the environment in order to be used by management to manage environmental aspects.

The management of environmental aspects requires data in both physical units and monetary units. Physically, the data relate to the input required in the production process in the form of materials, water and energy as well as data on outputs produced in the form of products and non-products (including waste and emissions). Monetary unit is the data in question, which is the cost data associated with inputs and outputs, issued by the company to reduce the environmental impact.

Physical data are used to determine the level of environmental impact that has been affected so that it can be controlled. Based on the data, the information related to the level of emissions produced might be generated, including the amount of waste produced and the processed, which is needed to determine the target of emission reduction, waste, and other protection.

The monetary data are more widely used in cost control in order that the management has a basis to manage the environmental aspects of the company in order to reduce pollution levels and waste, produce environmentally friendly products, so that environmental performance of the company can be improved (Bosshard, 2003, IFAC, 2005).

\section{METHODS OF RESEARCH}

This is a descriptive research with qualitative approach which is intended to describe a certain condition or phenomenon. The data were collected through observation on financial statements of the relevant companies and in-depth interviews with the companies.

The research was conducted in Emdeki Utama, Ltd. located on Jl. Raya Number 294, Driyorejo village, Gresik regency, East Java, Indonesia. The company has been running business to produce carbide. At the same time, the company has implemented a policy on environmental costs as well as corporate social responsibility (CSR) on the environmental aspect as well as on the surrounding communities. The analytical method used in this research was non-statistic method which is suitable if applied with a descriptive research.

\section{RESULTS AND DISCUSSION}

Emdeki Utama, Ltd. has produced carbide since 1987. Carbide is a versatile chemical, grain-shaped solid gray. If it is reacted with water, calcium carbide will produce asitelin gas.

Asitelin gas is used for metal cutting, metal welding, fuel lamps and chemical industry raw materials such as PVC seeds and batadinol. Utilization of asitelin gas produced by carbide for welding and cutting metal can be found in almost all construction industry, shipping, and other heavy industries. In the agricultural sector, carbide is used as a bundle of fruits to ripe as planned and together with an interesting color.

In addition to producing carbide, of course, the production process of this material also produces waste, namely in the form of carbide dust, lime powder, water, gas and particles. Carbide dust and lime powder are commonly stored and can be used for building material foundation, while the waste in the form of water needs to be processed first before it is flowed into the river.

The environmental costs make it easier for companies to disclose environmental information financially (Burritt, 2002). For Emdeki Utama, Ltd., the environmental cost covers total investment and production costs, environmental cost report and laboratory test in 2011 and 2012.

Total investment issued by Emdeki Utama, Ltd. in 2011 and 2012 did not increase, but the allocation for total productions increased by IDR 30,000,000,000. The increase in total production costs may indicate an increase in carbide production by Emdeki Utama, Ltd. 
The environmental cost report presented in Table 2 underlines the importance of the environmental costs by declaring it in percentage of the total production costs of the company.

Table 1 - Total Investment and Production Costs

\begin{tabular}{|c|c|c|}
\hline \multirow{2}{*}{ Information } & \multicolumn{2}{|c|}{ Total (IDR) } \\
\cline { 2 - 3 } & 2011 & 2012 \\
\hline Total investment & $200,000,000,000$ & $200,000,000,000$ \\
\hline Total production costs & $120,000,000,000$ & $150,000,000,000$ \\
\hline
\end{tabular}

Source: data processed from Emdeki Utama, Ltd.

Table 2 - Environmental Cost Report in 2011 and 2012

\begin{tabular}{|c|c|c|c|c|c|}
\hline \multirow[b]{2}{*}{ № } & \multirow[b]{2}{*}{ Information } & \multicolumn{2}{|c|}{2011} & \multicolumn{2}{|c|}{2012} \\
\hline & & Environmental cost & $\begin{array}{c}\% \text { of total } \\
\text { investment }\end{array}$ & $\begin{array}{c}\text { Environmental } \\
\text { cost }\end{array}$ & $\begin{array}{c}\% \text { of total } \\
\text { investment }\end{array}$ \\
\hline I & $\begin{array}{l}\text { Investment cost on machine } \\
\text { utilized to environmental cost } \\
\text { Early development } \\
\text { Annual } \\
\text { Total } \\
\text { Converted into operational } \\
\text { costs: } \\
\text { Depreciation of machine } \\
\text { (7 years flat) } \\
\text { Annual } \\
\text { Total }\end{array}$ & $\begin{array}{c}10,000,000,000 \\
50,000,000 \\
10,050,000,000\end{array}$ & $5.03 \%$ & $\begin{array}{c}10,000,000,000 \\
60,000,000 \\
10,060,000,000\end{array}$ & $5.03 \%$ \\
\hline II & $\begin{array}{l}\text { Operational costs and } \\
\text { equipment maintenance } \\
\text { Bag filter maintenance } \\
\text { Spare part maintenance } \\
\text { Man power maintenance } \\
\text { Heavy equipment maintenance } \\
\text { Operasional operator } \\
\text { Total }\end{array}$ & $\begin{array}{c}1,050,624,000 \\
267,000,000 \\
46,226,400 \\
108,000,000 \\
69,339,600 \\
1,541,190,000\end{array}$ & $1.28 \%$ & $\begin{array}{c}1,575,936,000 \\
340,000,000 \\
51,285,600 \\
129,000,000 \\
76,928,400 \\
2,173,750,000\end{array}$ & $1.45 \%$ \\
\hline III & $\begin{array}{l}\text { Environmental settlement } \\
\text { costs: } \\
\text { Non-B3 waste disposal of } \\
\text { Cleansing } \\
\text { Total }\end{array}$ & $\begin{array}{l}500,000,000 \\
231,132,000 \\
731,132,000\end{array}$ & $0.61 \%$ & $\begin{array}{l}600,000,000 \\
256,428,000 \\
856,428,000\end{array}$ & $0.57 \%$ \\
\hline IV & $\begin{array}{l}\text { Social and neighborhood } \\
\text { costs: } \\
\text { Provision of public health } \\
\text { facilities } \\
\text { Scholarships for community } \\
\text { Electricity of local mosques } \\
\text { Environmental team } \\
\text { Other spending } \\
\text { Total }\end{array}$ & $\begin{array}{c}59,124,000 \\
8,112,000 \\
3,600,000 \\
3,600,000 \\
60,000,000 \\
134,436,000\end{array}$ & $0.11 \%$ & $\begin{array}{c}79,785,600 \\
\\
9,456,000 \\
4,800,000 \\
4,800,000 \\
72,000,000 \\
170,841,600\end{array}$ & $0.11 \%$ \\
\hline Tot & & $3,885,329,429$ & $3.24 \%$ & $4,689,591,029$ & $3.13 \%$ \\
\hline
\end{tabular}

Source: data processed from Emdeki Utama, Ltd.

The allocation of construction cost or purchase of waste handling machine did not increase from 2011 to 2012. In contrast, all components of environmental costs have increased from 2011 to 2012 . This shows that the company is paying more attention to the environmental preservation. For example in the maintenance of bag filter, which is a tool to filter the dust from the production process has increased approximately IDR 500,000,000. The company also increased the allocation of social neighborhood costs for local community around the company. This allocation is expected to improve the quality of life of the community around the company. 


\begin{tabular}{|c|c|c|c|c|}
\hline \multicolumn{5}{|c|}{ Ambient Air } \\
\hline \multicolumn{5}{|c|}{ Parking Area of Emdeki Utama, Ltd. } \\
\hline \multirow{2}{*}{ Number } & \multirow{2}{*}{ Information } & \multirow{2}{*}{ Quality standard } & 2011 & 2012 \\
\hline & & & \multicolumn{2}{|c|}{ Average test results } \\
\hline \multirow{9}{*}{1} & Sulfur dioxide (SO2) & 0.1 & 0.0016 & 0.0086 \\
\hline & Carbon monoxide $(\mathrm{CO})$ & 20.0 & $<\mathrm{LD}$ & $<\mathrm{LD}$ \\
\hline & Nitrogen dioxide (NO2) & 0.05 & 0.0032 & 0.0197 \\
\hline & Oxidant (O3) & 0.10 & 0.0014 & 0.0136 \\
\hline & Dust & 0.26 & 0.071 & 0.201 \\
\hline & Lead $(\mathrm{Pb})$ & 0.06 & $<\mathrm{LD}$ & $<\mathrm{LD}$ \\
\hline & Hydrogen Sulfide (H2S) & 0.03 & 0.0002 & 0.0001 \\
\hline & Ammonia (NH3) & 2.0 & 0.0027 & 0.0751 \\
\hline & Noise & - & 62.3 & 60.2 \\
\hline \multicolumn{5}{|c|}{ Power Plant Area of Emdeki Utama, Ltd. } \\
\hline \multirow[t]{9}{*}{ 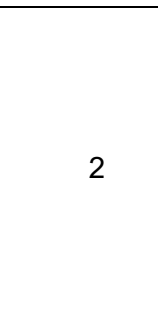 } & Sulfur dioxide (SO2) & 0.1 & 0.0015 & 0.0049 \\
\hline & Carbon monoxide (CO) & 20.0 & $<\mathrm{LD}$ & $<\mathrm{LD}$ \\
\hline & Nitrogen dioxide (NO2) & 0.05 & 0.0019 & 0.0224 \\
\hline & Oxidant (O3) & 0.10 & 0.0016 & 0.0162 \\
\hline & Dust & 0.26 & 0.124 & 0.112 \\
\hline & Lead $(\mathrm{Pb})$ & 0.06 & $<\mathrm{LD}$ & 0.0002 \\
\hline & Hydrogen Sulfide (H2S) & 0.03 & 0.0002 & 0.0001 \\
\hline & Ammonia $(\mathrm{NH} 3)$ & 2.0 & 0.0036 & 0.0633 \\
\hline & Noise & - & 58.4 & 61.8 \\
\hline \multicolumn{5}{|c|}{ Chimney Emission of Lime klin of Emdeki Utama, Ltd. } \\
\hline \multirow[t]{4}{*}{ 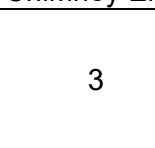 } & Sulfur dioxide (SO2) & 800 & 2.612 & 93.31 \\
\hline & Nitrogen dioxide (NO2) & 1000 & 9.388 & 0.52 \\
\hline & Total particulates & 100 & 7.00 & 44.26 \\
\hline & Opacity & 30 & $<5$ & 5 \\
\hline \multicolumn{5}{|c|}{ Chimney Emission of Furnance of Emdeki Utama, Ltd. } \\
\hline \multirow[t]{4}{*}{ 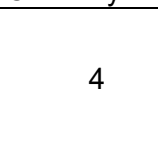 } & Sulfur dioxide (SO2) & 800 & 52.245 & 2.61 \\
\hline & Nitrogen dioxide (NO2) & 1000 & 9.388 & 0.48 \\
\hline & Total particulates & 100 & 13.40 & 75.46 \\
\hline & Opacity & 30 & $<5$ & 5 \\
\hline
\end{tabular}

Source: Emdeki Utama, Ltd.; $<L D=$ limit detection.

Table 4 - Results of Industrial Water Waste

\begin{tabular}{|c|c|c|c|c|}
\hline \multicolumn{5}{|c|}{ Industrial Water Waste Test } \\
\hline \multicolumn{5}{|c|}{ Parking Area of Emdeki Utama, Ltd. } \\
\hline \multirow{2}{*}{ Number } & \multirow{2}{*}{ Information } & \multirow{2}{*}{ Quality standard } & 2011 & 2012 \\
\hline & & & \multicolumn{2}{|c|}{ Average test results } \\
\hline \multirow{4}{*}{1} & Physical & & & \\
\hline & Temperature & 40 & 29 & 29 \\
\hline & Total dissolved solids (TDS) & 4000 & 1090 & 921 \\
\hline & Total suspended solids (TSS) & 200 & 7 & 2 \\
\hline \multirow{17}{*}{2} & Chemical & & & \\
\hline & $\mathrm{pH}$ & $6-9$ & 8 & 7 \\
\hline & Iron & 15 & 0.2536 & $<\mathrm{LD}$ \\
\hline & Manganese & 5 & $<\mathrm{LD}$ & $<\mathrm{LD}$ \\
\hline & Barium & 3 & - & $<\mathrm{LD}$ \\
\hline & Copper & 3 & $<\mathrm{LD}$ & $<\mathrm{LD}$ \\
\hline & Zinc & 15 & $<\mathrm{LD}$ & $<\mathrm{LD}$ \\
\hline & Chromium hexavalent & 0.5 & $<\mathrm{LD}$ & $<\mathrm{LD}$ \\
\hline & Total chrome & 1 & $<\mathrm{LD}$ & $<\mathrm{LD}$ \\
\hline & Cadmium & 0.1 & $<\mathrm{LD}$ & $<\mathrm{LD}$ \\
\hline & Mercury & 0.005 & $<\mathrm{LD}$ & $<$ LD \\
\hline & Lead & 1 & $<\mathrm{LD}$ & $<\mathrm{LD}$ \\
\hline & Nickel & 0.5 & $<\mathrm{LD}$ & $<\mathrm{LD}$ \\
\hline & Ammonia is free & 5 & 0.0767 & 0.0013 \\
\hline & Nitrate & 30 & 9.5071 & 17.398 \\
\hline & Nitrite & 3 & 1.2655 & 1.2710 \\
\hline & Anionic detergent & 10 & 0.861 & 0.3112 \\
\hline
\end{tabular}

Source: Emdeki Utama, Ltd. 
Furthermore, after the company disclosed the environmental cost report, the next phase is to conduct laboratory tests to test and study whether by the allocation of the environmental costs is able to reduce the level of waste impact resulted from the production process.

The results of the ambient air test in the parking area, power plant area, and the lime chimney emission and furnace emissions of the company above show good results (significantly under the quality standard). This shows that the infrastructure and environmental preservation at Emdeki Utama, Ltd. is operating according to the standard of operation and also the regulation.

All components of wastes generated by Emdeki Utama, Ltd. are significantly below the quality standard. Proper infrastructure development and waste maintenance are primary consideration at the company, so that good results on the waste test can be maintained. The realization of the company's commitment is the construction of infrastructure to preserve waste water first before it is channeled into the river so as it is not to disrupt the river ecosystem.

The final result of this research indicates that as the allocation of the environmental cost Emdeki Utama, Ltd. has proven that it is effective to reduce some components of waste, and the results of waste test were significantly below the quality standard, even though the production costs have increased. Given the increase in production costs, it may indicate that there is also the rise in the total carbide production. Emdeki Utama, Ltd. also consistently conducts three environmental impact management programs namely water quality management, air quality management, and noise pollution management.

\section{CONCLUSION}

According to the elaboration, there are some conclusions as follows:

Emdeki Utama, Ltd. has complied with Articles 2 and 3 of Government Regulation Number 47 of 2012 on Social and Environmental Responsibilities by companies, by contributing to the surrounding community in the area of health and education. In addition, the company also incorporates the environmental cost components in the company's operational processes.

The implementation of the environmental costs at Emdeki Utama, Ltd. has proven that it is effective to reduce the environmental impacts (waste content) resulted from the production process.

\section{ACKNOWLEDGMENTS}

This research was conducted by a joint research team organized by Faculty of Administrative Science (FIA) and Institute of Research and Community Service (BPP-FIA), University of Brawijaya. Members of the team are Dindha Ayu Mitra Dyani (Faculty of Administrative Science) and students of the Faculty of Administration Sciences. The research team expresses their gratitude to the Director of Institute of Research and Community Services (BPP-FIA), University of Brawijaya which has granted the collaborative Research Grant 2017.

\section{REFERENCES}

1. Bosshard, R.E. (2003) Environmental Accounting: A Case Study of its Application to a Small Business in Atlantic Canada. Theses, Dalhousie University Halifax, Nova Scotia

2. Burnett, R.D. dan D.R. Hansen. 2008 Ecoefficiency: Defining a role for environmental cost management. Accounting, Organizations and Proceedings SNEB 2014: Hal. 6 Society, Vol. 33, pp. $551-581$

3. Hansen, D. R. and Mowen, M. M. 2009. Akuntansi manajemen. Edisi Kedelapan. Buku 2. Yogyakarta: Graha Ilmu. 
4. Ikhsan, A. 2008. Akuntansi Lingkungan \& Pengungkapannya. Edisi Pertama. Yogyakarta: Graha IImu.

5. Pearce, David, et al. Sustainable Development, Economics and Environmental on the Third World. Great Britain: Routledge

6. Peraturan Pemerintah No. 47 Tahun 2012 tentang "Tangggung Jawab Sosial dan Lingkungan".

7. Sunu, P. 2001. Melindungi dengan Menerapkan ISO 14.000. Jakarta: PT. Grasindo.

8. Wijaya, M. 2012. Faktor-Faktor yang Mempengaruhi Pengungkapan Tanggug Jawab Sosial pada Perusahaan Manufaktur yang Terdaftar di Bursa Efek Indonesia. Jurnal IImiah Mahasiswa Akuntansi. No. 1 ; 26-30

9. Zulganef. 2008. Metode Penelitian Sosial \& Bisnis. Edisi Pertama. Yogyakarta: Graha IImu.

10. Electronic Source: http://emdeki.co.id/produk/proses-produksi.html 